Proceedings of the 2018 International Scientific Conference 'Economic Sciences for Agribusiness and Rural Economy' No 1, Warsaw, 7-8 June 2018, pp. 221-228

\title{
ECONOMIC STATUS OF FARMS IN POLAND AND SPAIN IN THE YEARS 2011-2016 BASED ON FADN STATISTICS
}

\author{
Xesus Pereira Lopez, Professor'; Manuel Veiga Carballido, Professor ${ }^{2}$; \\ Małgorzata Węgrzyńska, Eng $\mathrm{PhD}^{3}$; Magdalena Śmiglak-Krajewska, Eng $\mathrm{PhD}^{4}$
}

1,2 Faculty of Business Administration and Management, University of Santiago de Compostela

${ }^{3,4}$ Faculty of Economics and Social Sciences, Poznań University of Life Sciences

\begin{abstract}
The paper presents a comparison of the economic status of farms in two selected EU countries, Poland and Spain, in the period of 2011-2016. Both these countries were selected based on comparable qualitative and quantitative parameters characteristic of agriculture. An additional determinant for the selection of these countries was connected with the similar economic situation before and after their accession to the European Union. The economic status of these two countries was compared using the statistical data of the European Farm Accountancy Data Network (FADN), the Macroeconomic Data Bank (Poland) and the Instituto Nacional de Estadistica (Spain). In turn, the economic situation of farms in Poland and Spain was assessed on the basis of selected economic measures: Gross Farm Income, Farm Net Value Added, Farm Net Value Added/AWU, Family Farm Income/FWU, Total output of crops and crop production, total crops output (ha), total output of livestock and livestock products, total livestock output (LU), Total assets, total fixes assets, Total labour input and unpaid labour input. The study was summarised with the conclusions.
\end{abstract}

Keywords: common agricultural policy, economic measures, agriculture in Spain, agriculture in Poland JEL codes: M40, M41, M42

\section{INTRODUCTION}

The agricultural sector in the European Union has undergone considerable changes in recent years. The above resulted mainly from the stimulating influence of Common Agricultural Policy payments on the competitiveness of the EU agricultural sector as well as growing levels of economic interdependence in the EU. Globalization and improved access to foreign markets have enabled the European agri-food sector to compete with global food producers (Pawlewicz and Pawlewicz, 2018; after Ajitabh and Momaya, 2003). Polish-Spanish cooperation has been deepening for over 20 years. The Treaty of Friendship and Cooperation between the Republic of Poland and the Kingdom of Spain was signed in 1992, and came into force in 1994. While the Spanish economy was booming (1996-2007) Spain was an interesting

${ }^{1}$ Corresponding author: Avda. de Afonso X O Sabio, s/n. 27002 Lugo, Spain, xesus.pereira@usc.es

${ }^{2}$ Corresponding author: Avda. de Afonso X O Sabio, s/n. 27002 Lugo, Spain, mvcarb.veiga@usc.es

${ }^{3}$ Corresponding author: Wojska Polskiego 28, 60-637 Poznań, Poland, malgorzata.wegrzynska@up.poznan.pl

${ }^{4}$ Corresponding author: Wojska Polskiego 28,60-637 Poznań, Poland, smiglak@up.poznan.pl 
economic model for Poland. The Spanish experience of accession to the EU was also useful for Poland during its own negotiation process. Not only had both countries experienced smooth transitions to democracy, but they had also focused their foreign policy on becoming core EU countries. Since 2003 they have held annual intergovernmental summits at the prime ministerial level, leading to the construction of a common agenda. Consequently, political and economic dialogue has been improving constantly, while bilateral relations have become more symmetrical and balanced (Elcano Policy Paper 2/2013). Within the last century both Spain and Poland have undergone revolutionary economic changes, thanks to which both countries have changed the character of their economies, transformed from that based primarily on agriculture to economy dominated by the secondary and tertiary sectors. In the opinion of Perez-Méndez (1992) 'the direction of development for a country's economy is focused on the development of economy based on the services and the industry rather than agriculture'. That author stressed that the resources of agriculture are not adequately used and this does not facilitate attainment of its entire potential. When comparing the volume of investments per agricultural worker per farm and per 1 ha of farm area in Spain and in Poland it is evident that these values are lower than the mean for the European Union (EU) in other branches of the economy (Carballido Veiga, 2013). Additionally, the character of agriculture is different from that of the other branches of the national economy.

Nevertheless, we need to remember that over millennia agriculture was developing into two basic models of farms, i.e. family farms and large commercial farms. In view of the above, Klepacki (2005) distinguished three groups of farms operating in Polish agriculture:

1. Small farms, which are treated by their owners as a place of residence and (or) as a capital investment, and not as an entity of commercial agricultural production.

2. Intensively developing farms, characterised by the growing land area, development of production, e.g. through investments and a high degree of market integration.
3. Large market-oriented farms, characterised by simplified large-scale production, which may be easily mechanised.

We need to remember that irrespective of the size of a given farm and its legal ownership type each farm 'is a set of assets and rights organised by the owner to meet the requirements of agricultural production, mainly for commercial purposes. It is the primary source of income for the family, it may provide the family with means to maintain the socio-economic status comparable to the standard for other sectors' (Carballido Veiga, 2013). In order to ensure a similar socio-economic standard both Spain and Poland declared to accept the Community acquis, including also law regulating the Common Agricultural Policy (CAP). The principles and instruments of the common agricultural policy were stipulated in the Treaty of Rome of 1957 and subsequently specified at the Stresa conference in July 1958, entering into force in 1962 (Molle, 2017). In accordance with Article 39 of the Treaty the CAP is assigned the following objectives (Wieliczko, 2013): to increase the efficiency of agricultural production, by supporting technical change and ensuring rational development of agricultural production and optimal utilisation of production factors, particularly labour; to ensure a decent standard of living for rural communities, mainly by increasing individual incomes of individuals employed in agriculture; to stabilise markets; to ensure availability of supplies; and to guarantee prices. The Stresa conference also addressed the problem of methods to be applied to reach these objectives. In the future the common agricultural policy was to be modified by three primary principles (Tracy, 1994; Bieluk et al., 2012): (1) Market unity, i.e. throughout the Community prices of agricultural products should be unified, while trade in these products should be free; (2) Preferences for the Community: a system of customs barriers should be established to protect the internal market against instability of world markets; (3) Financial solidarity: a common fund should be created to finance common expenditure in the agricultural sector.

The aim of this paper is comparison of the economic status of farms in Poland and Spain, in the period of 2011-2016 on the basis of selected economic measures. 


\section{MATERIALS AND METHODS}

The paper is based on statistical data concerning specific branches of agriculture in two selected EU countries, i.e. Poland and Spain. Statistical data used in this paper refer to the period from 2011 to 2016, such as reports of the European Statistical Office - Eurostat, FADN, the Macroeconomic Data Bank (Poland) and the Instituto Nacional de Estadistica (Spain). Next the objectives specified in the Common Agricultural Policy were analysed and evaluated of certain indicators of economic efficiency, such as: Gross Farm Income, Farm Net Value Added, Farm Net Value Added/AWU, Family Farm Income/FWU, Total output crops and crop production, total crops output (ha), total output livestock and livestock products, total livestock output (LU), Total assets, total fixes assets, Total labour input and unpaid labour input. Subsequently conclusions were formulated.

\section{RESULTS AND DISCUSSION}

The share of the agricultural sector in the EU countries in the generation of GDP in 2015 was on average approx. $1.2 \%$ and the European Union for many years has been a net exporter of agricultural products. Poland (2.2\%) and Spain (2.5\%), next to Bulgaria, Estonia, Greece, Lithuania, Latvia, Romania and Hungary, are countries with the share of agriculture in GDP exceeding 2\% (World Bank, 2017). The share of agriculturally utilised area in the total area in 2015 in the EU was 184.5 million ha, in Poland it was 14.5 million ha and in Spain it was 26.3 million ha. Both countries are characterised by a considerable fragmentation of farms owned by individual farmers. In relation to the total number of farms in Poland, small farms with an area of max. 5 ha accounted for as much as 55\%, while in Spain it was 53\% (GUS, 2017). Such a significant fragmentation of farms is highly disadvantageous for the development of agriculture. Among other things, it limits the potential of increasing the marketable value of agricultural production.

The first and at the same time the basic statistic concerning agricultural income is provided by the Gross Farm Income, being the most important measure defining economic efficiency of farm resources.
Gross income of Polish farms in the years 2011-2016 was considerably lower than in Spain (Table 1). The average income was only EUR 16 thousand, while in Spain it exceeded EUR 38 thousand. We need to focus particularly on the fluctuations of changes in income. Revenue of Polish farms starting from 2016 in relation to 2011 decreased by $14 \%$, while in Spanish farms it increased by as much as $71 \%$.

Differences in the volume of income generated from agriculture in individual countries result from many factors, particularly structural differences, i.e. farm size, directions of production, ownership structure and the initial condition of agriculture in the accession period, as it was presented by Zawalińska, Majewski and Wąs (2015).

Information on income structure of farms is also provided by the statistic concerning value added generated by farms. In the analysed period net value added for farms in Poland was over 2-fold lower than that of farms in Spain. Value added in Polish farms in 2016 was by $23 \%$ lower in comparison to 2011 , while in Spain it increased by almost $73 \%$. According to a study by Czyżewski and Kryszak (2015) in the years 2007-2012 the rate of change in value added in Poland was $7.8 \%$, while Spanish farms recorded a decrease by $19.5 \%$. In this context it may be disturbing that in recent years value added in Poland has been decreasing from year to year.

An important aspect in the evaluation of farms is also connected with the analysis of labour efficiency. It is expressed in the value of standardised production per one Annual Work Unit (AWU). Analysis of data presented in Table 1 indicates that a greater efficiency was recorded in Spain (average EUR 19,492). The low effects in Poland (average EUR 6,741) may result from the low price levels for agricultural products. Next to Malta, Cyprus, Slovenia and Romania, Poland is a country with one of the lowest labour efficiencies in the EU (Sadowski et al., 2015).

The primary measure informing on economic efficiency is provided by income from a farm expressed in value per Family Work Unit (FWU). Labour profitability in farms in Spain increased in the period of 2011-2016 from EUR 21,083/FWU to EUR 34,699/FWU, while in Poland it decreased from EUR 6,976/FWU to EUR 5,318/FWU and it was almost 7-fold lower. 
Proceedings of the 2018 International Scientific Conference 'Economic Sciences for Agribusiness and Rural Economy' No 1, Warsaw, 7-8 June 2018, pp. 221-228

Table 1. Gross Farm Income, Farm Net Value Added, Farm Net Value Added / AWU, Family Farm Income / FWU in years 2011-2016 in Spain and in Poland

\begin{tabular}{|c|c|c|c|}
\hline Year & Specification & Spain & Poland \\
\hline \multirow{4}{*}{2011} & Gross Farm Income & 31936 & 17018 \\
\hline & Farm Net Value Added & 28830 & 12802 \\
\hline & Farm Net Value Added / AWU & 20619 & 7444 \\
\hline & Family Farm Income / FWU & 21083 & 6976 \\
\hline \multirow{4}{*}{2012} & Gross Farm Income & 32042 & 17160 \\
\hline & Farm Net Value Added & 28555 & 12895 \\
\hline & Farm Net Value Added / AWU & 20261 & 7484 \\
\hline & Family Farm Income / FWU & 20078 & 6930 \\
\hline \multirow{4}{*}{2013} & Gross Farm Income & 32738 & 16685 \\
\hline & Farm Net Value Added & 29292 & 11904 \\
\hline & Farm Net Value Added / AWU & 21393 & 7017 \\
\hline & Family Farm Income / FWU & 21246 & 6510 \\
\hline \multirow{4}{*}{2014} & Gross Farm Income & 32786 & 15635 \\
\hline & Farm Net Value Added & 27855 & 10751 \\
\hline & Farm Net Value Added / AWU & 20317 & 6441 \\
\hline & Family Farm Income / FWU & 19593 & 5804 \\
\hline \multirow{4}{*}{2015} & Gross Farm Income & 48383 & 14868 \\
\hline & Farm Net Value Added & 43173 & 9927 \\
\hline & Farm Net Value Added / AWU & 26416 & 6045 \\
\hline & Family Farm Income / FWU & 28160 & 5427 \\
\hline \multirow{4}{*}{2016} & Gross Farm Income & 54806 & 14651 \\
\hline & Farm Net Value Added & 49834 & 9802 \\
\hline & Farm Net Value Added / AWU & 28059 & 6018 \\
\hline & Family Farm Income / FWU & 34699 & 5318 \\
\hline
\end{tabular}

Source: the authors' study based on: Farm Accountancy Data Network, Instituto Nacional de Estadistica (Spain).

The FADN data indicate that plant production predominated over animal production in both analysed countries (Table 2). The volumes of plant and animal production were greater in Spain (Table 2). The value of plant production in 2016 in comparison to the initial period of analysis in Spain increased by approx. $81 \%$, while that of animal production - by approx.
$51 \%$. In the analogous period in Poland the value of plant and animal production decreased (for plant production it was by approx. $10 \%$, while for animal production - by $12 \%$ ). Per 1 ha the mean value of plant production in Poland was higher than in Spain, i.e. EUR 841, at EUR 838 in Spain. Animal production per 1 ha in Poland is also higher, on average amount- 
Proceedings of the 2018 International Scientific Conference 'Economic Sciences for Agribusiness and Rural Economy' No 1, Warsaw, 7-8 June 2018, pp. 221-228

Table 2. Total output crops and crop production, total crops output (ha), total output livestock and livestock products, total livestock output (LU) in years 2011-2016 in Spain and Poland

\begin{tabular}{|c|c|c|c|}
\hline Year & Production & Spain & Poland \\
\hline \multirow{4}{*}{2011} & Total output crops \& crop production & 29004 & 16027 \\
\hline & Total crops output / ha & 896 & 850 \\
\hline & Total output livestock \& livestock products & 19423 & 12920 \\
\hline & Total livestock output / LU & 795 & 979 \\
\hline \multirow{4}{*}{2012} & Total output crops \& crop production & 31993 & 17592 \\
\hline & Total crops output / ha & 885 & 936 \\
\hline & Total output livestock \& livestock products & 17625 & 12232 \\
\hline & Total livestock output / LU & 781 & 1044 \\
\hline \multirow{4}{*}{2013} & Total output crops \& crop production & 32574 & 16289 \\
\hline & Total crops output / ha & 873 & 865 \\
\hline & Total output livestock \& livestock products & 19543 & 13474 \\
\hline & Total livestock output / LU & 831 & 1154 \\
\hline \multirow{4}{*}{2014} & Total output crops \& crop production & 32067 & 15153 \\
\hline & Total crops output / ha & 872 & 817 \\
\hline & Total output livestock \& livestock products & 18833 & 13441 \\
\hline & Total livestock output / LU & 858 & 1109 \\
\hline \multirow{4}{*}{2015} & Total output crops \& crop production & 47114 & 15065 \\
\hline & Total crops output / ha & 1081 & 812 \\
\hline & Total output livestock \& livestock products & 28210 & 12673 \\
\hline & Total livestock output / LU & 871 & 1042 \\
\hline \multirow{4}{*}{2016} & Total output crops \& crop production & 52667 & 14424 \\
\hline & Total crops output / ha & 1210 & 766 \\
\hline & Total output livestock \& livestock products & 29482 & 11423 \\
\hline & Total livestock output / LU & 868 & 942 \\
\hline
\end{tabular}

Source: authors'study based on: The Macroeconomic Data Bank (Poland), Farm Accountancy Data Network, Instituto Nacional de Estadistica (Spain).

ing to $882 \mathrm{LU}$ in comparison to $701 \mathrm{LU}$ in Spain. A typical characteristic of most farms in Poland is connected with the high value of fixed assets in relation to the owned agriculturally utilised area and a high share of fixed assets in the total value of assets
(Mańko and Płońka, 2010). The mean value of total property (assets) in farms in the analysed years in Poland exceeded EUR 16 thousand, while in Spain it was EUR 30 thousand (Fig. 1). In the first three years of the analysis the value of assets was decreasing 
Proceedings of the 2018 International Scientific Conference 'Economic Sciences for Agribusiness and Rural Economy' No 1, Warsaw, 7-8 June 2018, pp. 221-228

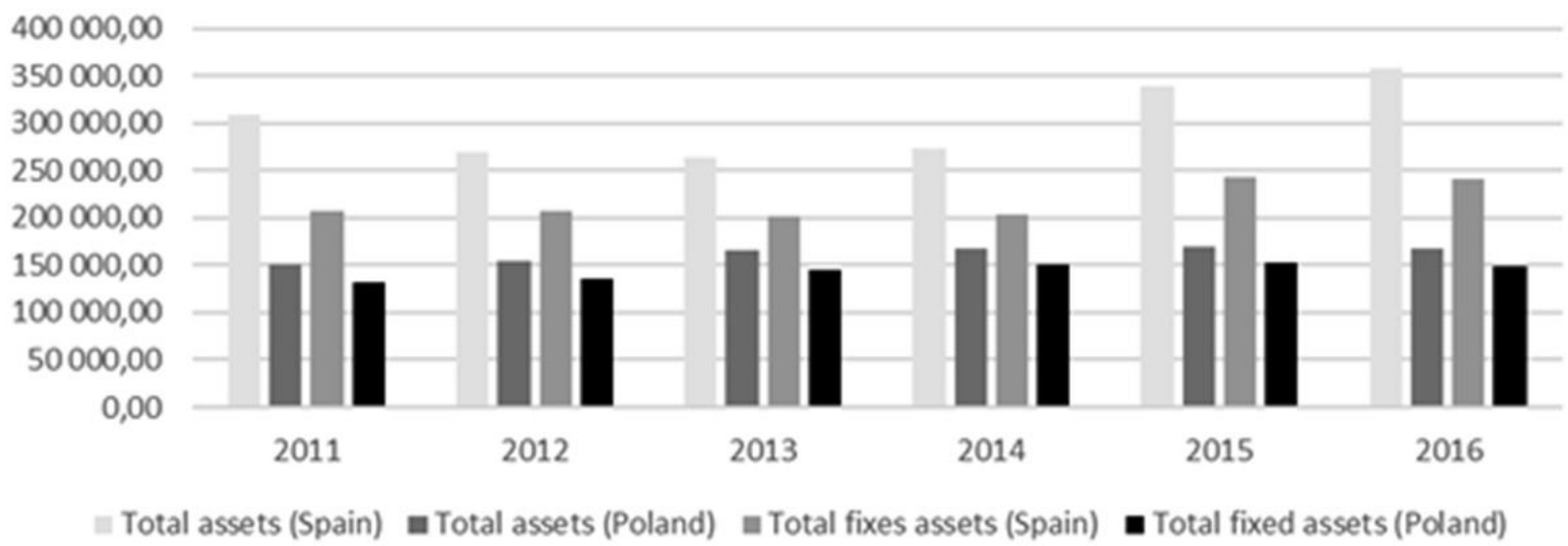

Figure 1. Total assets, total fixes assets in years 2011-2016 in Spain and Poland

Source: authors' study based on: Macroeconomic Data Bank, Farm Accountancy Data Network.

both in Poland and in Spain, while after 2014 it was increasing. In the investigated period the mean share of fixed assets in total assets in Poland was approx. $47 \%$, whereas in Spain it was around $42 \%$.

The population employed in agriculture comprised mainly residents of rural areas, for whom in the past income from employment in agriculture constituted the foundation for livelihood. As a consequence of economic development in both countries, particularly non-agricultural activity, the situation was changing markedly (Kapusta, 2014). The total Family Work Unit (FWU) in 2011 in Poland amounted to 1.72, while in 2016 it decreased to 1.63 (Fig. 2). The reduction in the total value of family work on a farm in Poland was connected, among other things, with considerable mechanisation of agriculture. This trend has been observed since 1992, with labour inputs per 1 farms systematically decreasing (Karwat-Woźniak, 2009).

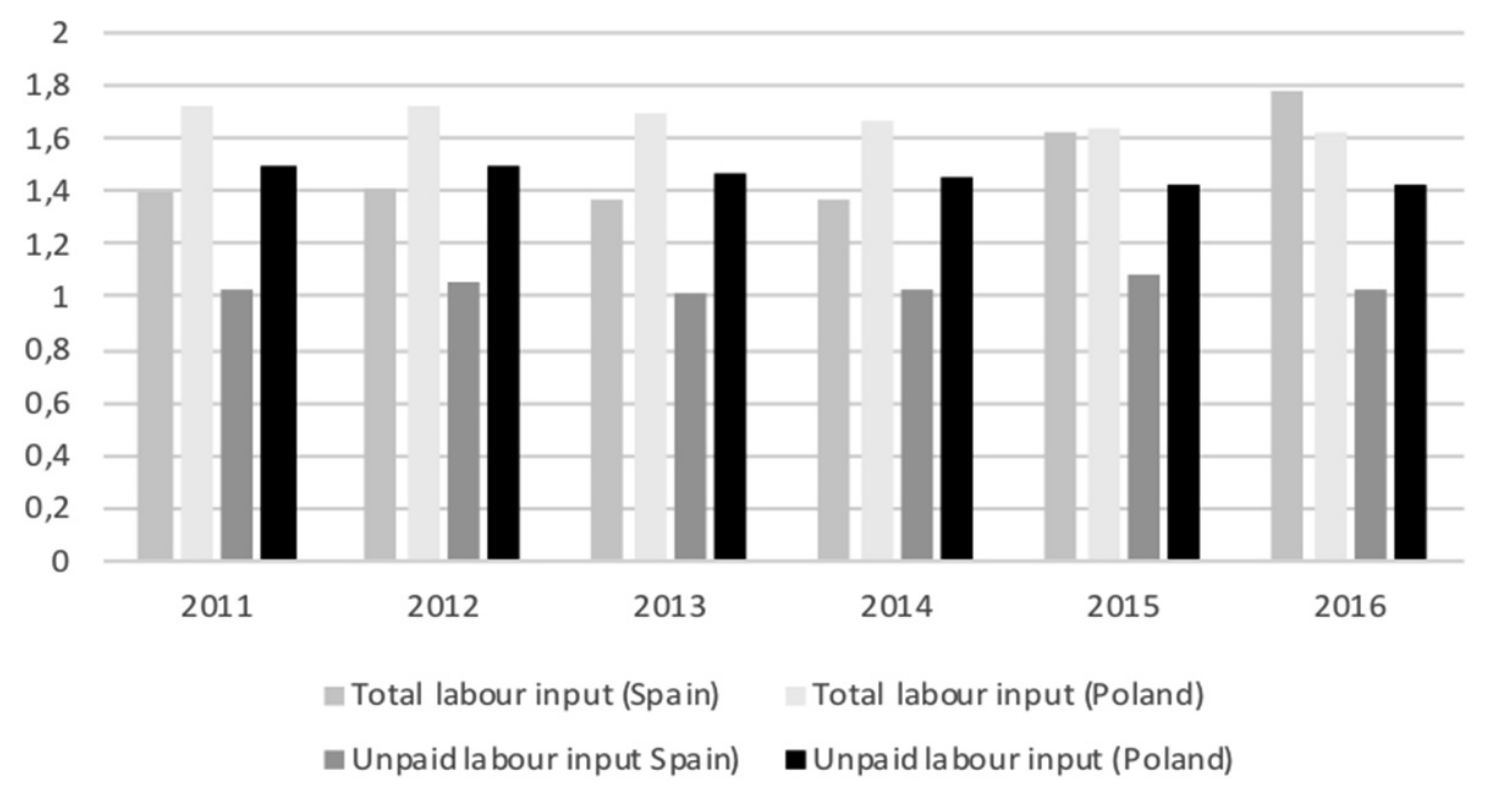

Figure 2. Total labour input and unpaid labour input in years 2011-2016 in Spain and Poland (FWU) Source: authors' study based on: Farm Accountancy Data Network. 
Additionally, the share of family work in the case of farmers in Poland was 1.49 in 2011, decreasing systematically to 1.43 and being by approx. $50 \%$ greater in comparison to Spain in the analogous period (Fig. 2).

\section{CONCLUSIONS AND RECOMMENDATIONS}

The results of the presented analysis point to significant differences in the productive potential of agriculture in Poland and Spain. Those discrepancies can be attributed to variations in geographic and natural conditions, type of agricultural production, population and economic development. The conducted comparative analysis of Polish farms covered by the FADN system with Spanish farms for the period of 2011-2016 showed that: Polish farms record poorer economic results, both in terms of gross and net income, as well as value added in comparison to Spanish farms. Higher volumes of plant and animal production in the investigated period were recorded in Spain. In turn, in Poland plant production was higher per 1 ha, while animal production was higher in terms of Livestock Units. The mean value of total assets in farms in the analysed years in Poland exceeded EUR 16 thousand, while in Spain it was EUR 30 thousand. In the analysed period the total value of family work in farms decreased both in Poland and Spain.

To fully achieve its growth potential, Polish agriculture would have to assist companies to increase investment in brand creation, and address the fragmented sectoral structure by encouraging consolidation of smaller farming units into larger business entities of a large enough scale to satisfy international demand.

\section{REFERENCES}

1. Ajitabh, A., Momaya, K.S. (2003). Competitiveness of Firms: Review of Theory, Frameworks and Models. Singapore Management Review, 26 (1), pp. 45-61.

2. Bieluk, J. et al. (2012). Z zagadnień prawa rolnego, cywilnego i samorządu terytorialnego [Problems in agrarian, civil and local goverment laws]. Wydawnictwo Temida 2, Białystok.

3. Carballido Veiga, M. (2013). Metodos para la valoracion contable de activos biologicos en empresas agrarias [Methods for the accounting valuation of bio- logical assets in agrarian companies]. Doctoral Thesis, Instituto de Estudios e Desenvolvimiento de Galicia Universidad de Santiago de Compostela, Lugo.

4. Czyżewski, A., Kryszak, Ł. (2015). Sytuacja dochodowa gospodarstw rolniczych w krajach UE-15 i w Polsce w latach 2007-2013 w świetle statystyki FADN [Income situation of agricultural holdings in EU-15 member states and Poland in the years 2007-2013 in the light of the FADN statistic]. Zeszyty Naukowe SGGW w Warszawie. Problemy Rolnictwa Światowego, 15 (30), 1, pp. 21-32.

5. Elcano Policy Paper (2013). Poland and Spain: How to Cooperate in a Europe in Flux, Elcano Royal Institute and the Polish Institute of International Affairs (PISM). Retrievedfrom:http:/www.realinstitutoelcano.org/wps/ wcm/connect/4a6ac500404d7558a0ebe1906ffb1a66/ Elcano-PolicyPaper-Poland-Spain-CooperationEurope-in-Flux.pdf?MOD=AJPERES\&CACHEID $=4 \mathrm{a} 6 \mathrm{ac} 500404 \mathrm{~d} 7558 \mathrm{a} 0 \mathrm{ebe} 1906 \mathrm{ffb} 1 \mathrm{a} 66 \quad$ [Accessed 26.08.2018].

6. GUS (2018). Rocznik Statystyczny Rolnictwa 2017 [Statistical Yearbook of Agriculture 2017]. Dział Wydawnictw Statystyznych GUS, Warszawa.

7. Kapusta, F. (2014). Zasoby i nakłady pracy w rolnictwie polskim [Capital and labour resources in Polish agriculture]. Roczniki Naukowe SERiA, 16 (1), pp. 91-97.

8. Karwat-Woźniak, B. (2009). Zatrudnienie w rolnictwie indywidualnym $\mathrm{w}$ okresie transformacji i integracji europejskiej [Employment in individual agriculture in the period of transition and European integration]. Journal of Agribusiness and Rural Development, 3 (13), pp. 73-81.

9. Klepacki, B. (2005). Tendencje zmian w ekonomicznej i społecznej strukturze wsi 2005. Tendencje zmian w ekonomicznej i społecznej strukturze wsi [Trends for changes in the economic and social structure of rural communities]. In: Wilkin, J. (ed.) Polska wieś 2025. Wizja rozwoju [Polish rural community 2025. Vision of development]. IRWiR PAN, Warszawa, pp. 85-89.

10. Mańko, S., Płońka, R. (2010). Struktura aktywów a wyniki działalności gospodarstw rolnych w świetle danych Polskiego FADN [The structure of assets and economic results of farms in view of data from Polish FADN]. Retrieved from: https://depot.ceon.pl/handle/123456789/5719 [Accessed 26.05.2018].

11. Molle, W. (2016). The Economics of European Integration. Theory, Practice, Policy. Routledge, London.

12. Pawlewicz, A., Pawlewicz, K. (2018). Regional differences in agricultural production potential in the European Union member states. In: Proceedings of the 2018 
International conference 'Economic Science for Rural Development' 47, Jelgava, 09.05.2018, pp. 483-489.

13. Perez-Mendez, J.A. (1992). Contabilidad y Gestion de la empresa ganadera. Analisis del sector ganadero asturiano [Accounting and Management of the livestock company. Analysis of the Asturian livestock sector]. Doctoral Thesis, Departamento de Administración de empresas y Contabilidad, Universidad de Oviedo, Oviedo.

14. Sadowski, A., Poczta, W., Szuba-Barańska, E., Beba P. (2015). Modele gospodarstw rolnych w państwach Unii Europejskiej [Models of farms in the European Union]. Wieś i Rolnictwo, 3 (168), pp. 43-62. Retrieved from: https://ageconsearch.umn.edu/bitstream/232012/2/20153-WiR-3.pdf [Accessed 26.05.2018].

15. Tracy, M. (1994). The spirit of Stresa. European Review of Agricultural Economics, 21 (3-4), pp. 357-374. https://doi.org/10.1093/erae/21.3-4.357

16. Treaty establishing the European economic community. OJ C 325 of 24.12.2002.
17. Wieliczko, B. (2013). Państwo a rynek w rolnictwie - rolnictwo Polski i UE w pierwszych dekadach XXI wieku [The state and the market in agriculture - Polish agriculture and the EU in the first decades of the 21st century]. In: Czyżewski, A., Klepacki, B. (eds.) Problemy rozwoju rolnictwa i gospodarki żywnościowej w pierwszej dekadzie członkostwa Polski w Unii Europejskiej [Problems of agriculture development and food economy in the first decade of Poland's membership in the European Union]. Polskie Towarzystwo Ekonomiczne, Warszawa 2015, pp. 154-165.

18. World Bank (2017). World development indicators. Retrieved from: http://databank.worldbank.org/data/reports.aspx [Accessed 22.08.2018].

19. Zawalińska, K., Majewski, E., Wąs, A. (2015). Długookresowe zmiany w dochodach z polskiego rolnictwa na tle krajów Unii Europejskiej [Long-term changes in the incomes of the Polish agriculture compared to the European Union countries]. Roczniki Naukowe SERiA, 17 (6), p. 353. 